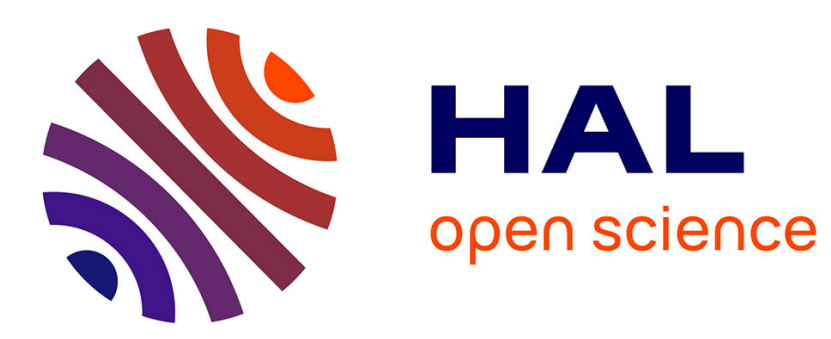

\title{
Estimation of flooded area in the Bahr El-Jebel basin using remote sensing techniques
}

M. A. H. Shamseddin, T. Hata, A. Tada, M. A. Bashir, T. Tanakamaru

\section{To cite this version:}

M. A. H. Shamseddin, T. Hata, A. Tada, M. A. Bashir, T. Tanakamaru. Estimation of flooded area in the Bahr El-Jebel basin using remote sensing techniques. Hydrology and Earth System Sciences Discussions, 2006, 3 (4), pp.1851-1877. hal-00298740

\section{HAL Id: hal-00298740 \\ https://hal.science/hal-00298740}

Submitted on 24 Jul 2006

HAL is a multi-disciplinary open access archive for the deposit and dissemination of scientific research documents, whether they are published or not. The documents may come from teaching and research institutions in France or abroad, or from public or private research centers.
L'archive ouverte pluridisciplinaire HAL, est destinée au dépôt et à la diffusion de documents scientifiques de niveau recherche, publiés ou non, émanant des établissements d'enseignement et de recherche français ou étrangers, des laboratoires publics ou privés. 
Hydrol. Earth Syst. Sci. Discuss., 3, 1851-1877, 2006 www.hydrol-earth-syst-sci-discuss.net/3/1851/2006/

(C) Author(s) 2006. This work is licensed under a Creative Commons License.
Hydrology and

Earth System

Sciences

Discussions

Papers published in Hydrology and Earth System Sciences Discussions are under open-access review for the journal Hydrology and Earth System Sciences

\section{Estimation of flooded area in the Bahr El-Jebel basin using remote sensing techniques}

M. A. H. Shamseddin ${ }^{1}$, T. Hata ${ }^{2}$, A. Tada ${ }^{3}$, M. A. Bashir ${ }^{2}$, and T. Tanakamaru ${ }^{2}$

${ }^{1}$ Water Management and irrigation institute, University of Gezira, P.O. Box 20, Wad Medani, Sudan

${ }^{2}$ Dept. of Food Systems and Field Sciences, Graduate School of Science and Technology, Kobe University, Nada, Kobe 657-8501, Japan

${ }^{3}$ Faculty of Agriculture, Kobe University, Japan

Received: 26 April 2006 - Accepted: 22 May 2006 - Published: 24 July 2006

Correspondence to: M. A. Bashir (bashir70us@yahoo.com)

HESSD

3, 1851-1877, 2006

Estimation of Bahr-El-Jebel flood area by remote sensing

M. A. H. Shamseddin et al.

\section{Title Page}

Abstract

Introduction

Conclusions

References

Tables

Figures

14

4

Back

Close

Full Screen / Esc

Printer-friendly Version

Interactive Discussion 


\section{Abstract}

In spite of the importance of Sudd (swamp) area estimation for any hydrological project in the southern Sudan, yet, no abroad agreement on its size, due to the inaccessibility and civil war. In this study, remote sensing techniques are used to estimate the

5 Bahr El-Jebel flooded area. MODIS-Terra (Moderate Resolution Imaging Spectroradiometer) level 1B satellite images are analyzed on basis of the unsupervised classification method. The annual mean of Bahr El-Jebel flooded area has been estimated at $20400 \mathrm{~km}^{2}$, which is $96 \%$ of Sutcliffe and Park (1999) estimation on basis of water balance model prediction. And only, 53\% of SEBAL (Surface Energy Balance Algorithm for Land) model estimation. The accuracy of the classification is $71 \%$. The study also found the swelling and shrinkage pattern of Sudd area throughout the year is following the trends of Lake Victoria outflow patterns. The study has used two evaporation methods (open water evaporation and SEBAL model) to estimate the annual storage volume of Bahr El-Jebel River by using a water balance model. Also the storage changes due 15 time is generated throughout the study years.

\section{Introduction}

Wetlands are a basic pillar for the earth ecosystem. However, wetlands subject to large variations, seasonally and annually (Travaglia et al., 1996). Flood protection, fisheries, groundwater recharge, moisture recycling, grazing and biodiversity are some of the main advantages of the wetlands. Moreover, wetlands are gets concerns also on environmental studies, as it considered as a Methane gas source (Yoshiki, 1999). On the other hand, in term of evaporation process to atmosphere, wetlands may consider as wasting water source.

The swamp area in Southern Sudan is one of the largest wetlands in Africa (Shahin, 25
HESSD

3, 1851-1877, 2006

\section{Estimation of Bahr-El-Jebel flood area by remote sensing}

M. A. H. Shamseddin et al.

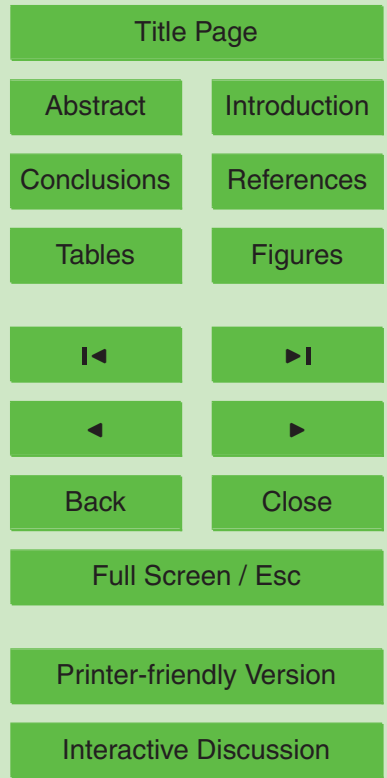


1996; Sutcliffe et al., 1999; Waterbury, 2002; Mohamed, 2005). Sutcliffe and Park (1999) have quoted the Newhouse (1929) description for Sudd area as "not a reservoir, where water stored, but a sink, where water wasted". Also the swamp considered as a barrier or dam blocking the flow (Shahin, 2002). The recent shortfalls in Ethiopia (Blue 5 Nile) and the population increase made the swamp area in southern Sudan under focus (Howell et al., 1996). It goes without saying that, swampy area reclamation is considered as a potential water resource of Sudan and Egypt, about 6.0 milliard cubic meters of water will be saved for Sudan from the swampy area reclamation (Eldaw, 2003). Jonglei canal is one of the projects that aimed to reduce water losses in Sudd

10 area (Sutcliffe et al., 1999; Howell et al., 1996; Waterbury, 2002; Mohamed, 2005). The onset of civil war, however, stopped the completion of the canal construction; moreover, yet, the environmental impacts of Jonglei canal construction are controversial issues (Mohamed et al., 2005; Waterbury, 2002; Howell et al., 1996).

Many studies about the swampy areas evaporation amount have carried out (An15 nex 1) (Sutcliffe et al., 1999; Mohammed et al., 2005), which were resulted in a confusing or a contradictory result. Hitherto, no broad agreement on evaporation estimation is reached. The fact may extract, however, from these evaporation estimation studies is that many discrepancies were found on the swampy areas estimation and/or delineation. It goes without saying that, many techniques were used for swamp area estimation (see Mohamed et al., 2005; Sutcliffe et al., 1999; Travaglia et al., 1996).

The difficulties of swamp area estimation might be due to the inaccessibility of the area, the vast areas of swamp, and the complexity of the dynamic behavior of the swamp throughout the year (permanents and seasonal flooded areas), and the civil war that raged out as well. On the other hand, revising the literature of Africa's continent wetland estimation shows the estimation of African's continent wetlands still in an infancy stage, (see http://www.fao.org/documents/), and the world's wetland as well.

The swamp area estimation is so important from hydrological, fishery, agricultural, environmental monitoring and economical point of views. Understanding the dynamic behaviors of the Sudd area throughout the year, besides figuring the link between hy-

HESSD

3, 1851-1877, 2006

\section{Estimation of Bahr-El-Jebel flood area by remote sensing}

M. A. H. Shamseddin et al.

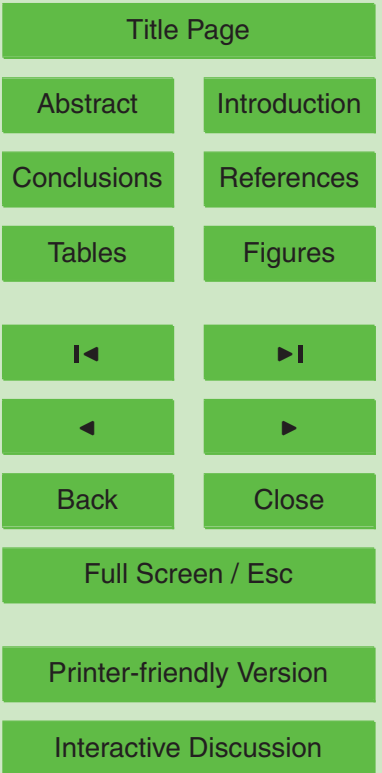


drological regime and the distribution of the vegetation of the flood plain are the key point for any future development projects in the Southern Sudan region. Such understanding now days can be achieved more easily, through using remote sensing and GIS techniques, especially nowadays, satellite sensors are advanced tremendously 5 and can provides huge amounts of time series data, and free of charges as well. In terms of Sudd water balance model, Sutcliffe and Park (1999) have mentioned that using further satellite imagery will refine their models of the Sudd water balance (Sutcliffe et al., 1999).

This paper aimed to better understanding of the dynamic behaviors of Sudd areas 10 throughout the year, to estimate the Sudd area, through using remote sensing techniques. Also the paper aimed to re-calculate the water balance model of the Sudd areas on the basis of time series satellite imagery analysis results.

\section{Study area literature}

The study area is located at the southern Sudan. The previous studies (Mohamed, 15 2005; Sutcliffe et al., 1999) have divided the area into three distinctive basins, Bahr El-Jebel, Bahr Al Ghazal and the Sobat basin (Fig. 1). Meanwhile, the area between Bahr El-Jebel and Ghazal is questionable (Mohamed, 2005). In terms of topography, the area can be divided into three categories, the high lands (free flooded), the intermediate land (seasonally flooded), and the permanent swamp (always under water) 20 (Howell, 1996). Table 1 shows the area normal annual means (1970-2000) of some selected climatic elements (means of Juba, Wau and Malakal stations). Figure 2 shows the area monthly rainfall normal mean (on the basis of Juba, Wau and Malakal stations normal mean). It is obvious that the peak of the rainfall is in August, whereas, the dry period extends from November to March.

25 Away of the swamp and wetland definitions complexity, the word "swamp" in this study refers to the three basins (above mentioned) swamps, whereas the word "Sudd" denote to Bahr El-Jebel swamp, only. Bahr El-Jebel River, which originates from Lake
HESSD

$3,1851-1877,2006$

\section{Estimation of Bahr-El-Jebel flood area by remote sensing}

M. A. H. Shamseddin et al.

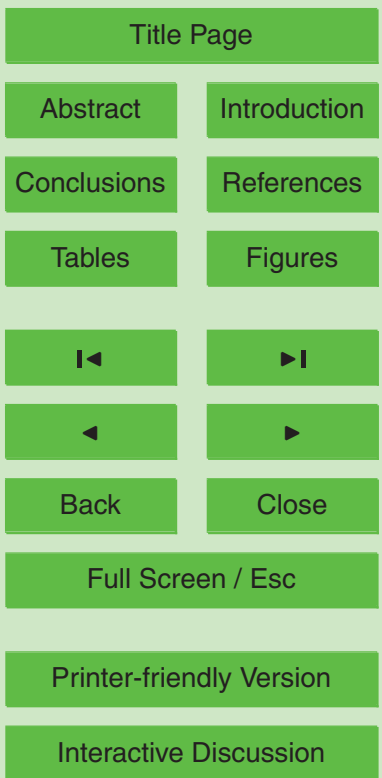


Victoria, is the most complex of the Nile reaches because of the torrents during the rainy season (Sutcliffe et al., 1999). About half of the White Nile River flow is lost in the Sudd area, because of evaporation. Table 2 shows the previous evaporation estimation of Sudd area. Howell (1996) stated that $88 \%$ increase of Bahr El-Jebel 5 river flows resulted, only in a $50 \%$ increase in the White Nile outflows; coupled with a $130 \%$ increase in Sudd area (Howell et al., 1996). And due to this appreciated losses Jonglei canal has been proposed. Actually two third of the canal $(260 \mathrm{~km})$ has been accomplished, and due to civil war onset it has stopped (Howell, 1996; Waterbury, 2002).

10 This study concerns on Bahr El-Jebel river swamp area $\left(6.5^{\circ}, 9.62^{\circ} \mathrm{N}\right.$ and $29.22^{\circ}$, $32.0^{\circ} \mathrm{E}$ ) that located downstream of Mongalla where the river is a single channel with low stage (Shahin, 2002), up to the confluence of the White Nile with the Sobat river at Malakal town, where the White Nile outflows is measured. The slope is generally very flat (Mohamed et al., 2005), the soil has developed on recent alluvium, with a high bulk 15 density and impermeability (Howell et al., 1996).

Due to the less channel capacities and the high flows, the excess flows of Bahr ElJebel river leave through small channels and inundated large areas on both sides of the river and created the swamp. During the rainy season, the torrents have a contribution in swamp area extension as well. However the outflows of Victoria Lake provide the available power of Sudd extension (Tate, 2004; Sutcliffe, 1999). The swamp has a vital role in the southern Sudan economy (i.e. grazing, fishery, etc.), hence any upstream water constructions (i.e. storage) should consider the impacts of these projects at downstream level (i.e. swamp).

\section{Materials and methods}

25 MODIS-Terra level $1 \mathrm{~B}$ calibrated Radiance $1 \mathrm{~km}$ resolution time series satellite images (Hierarchical Data Format, HDF) were ordered and downloaded from NASA website (http://daac.gsfc.nasa.gov/) (Appendix A), for the years 2001, 2002, 2003, 2004, and

\section{HESSD}

$3,1851-1877,2006$

\section{Estimation of Bahr-El-Jebel flood area by remote sensing}

M. A. H. Shamseddin et al.

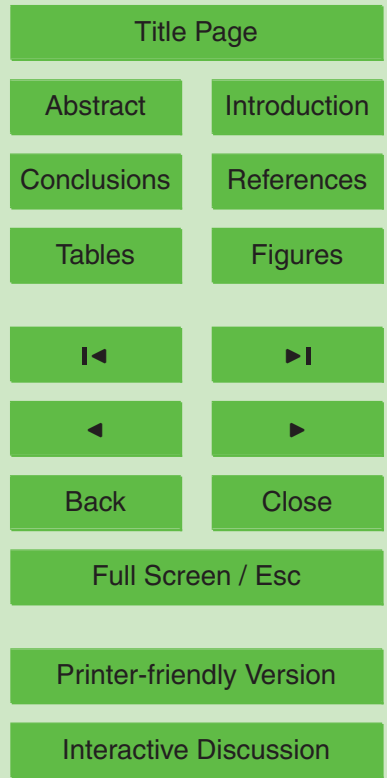


2005 (Appendix B), with a consideration of avoiding the cloud contamination. The Environment for Visualizing Images processing system (ENVI 4.2) has used to extract, visualize and analysis the images. The images were georeferenced on basis of UTM projection and WGS-84 datum. A subset via region of interest (ROI) and layer stacking 5 process was conducted. Due to lack of more ground truth data, the Isodata unsupervised classification techniques was used. The Isodata unsupervised classification calculates class means evenly distributed in the data space and then iteratively cluster the remaining pixels using minimum distance methods. To determine the suitable classes' number, a simple matrix error method was used. Four levels of verification 10 were carried out for the study's resulted images, which were, The NDVI values (using the red and infrared MODIS bands (Appendix C)), the vegetation map for Jonglei area (1983), which provided by Howell (2002), Landsat ETM+ image with $30 \mathrm{~m}$ resolution for Sudd area (downloaded from Global Land Cover Facilities website, GLCF), and MODIS natural color images (bands 1, 4, 3), and bands 3, 6, 7 combination (see 15 http://rapidfire.sci.gsfc.nasa.gov). The ENVI 4.2 change detection statistics method was used to compile a detailed tabulation of changes between the resulted classification images on basis of initial and final states (two consecutively images.

Sutcliffe and Parks (1999) hydrological model for Sudd area was used to calculate the monthly storage changes, and monthly Bahr El-Jebel basin water balance:

20

$\partial V=\{Q-q+A(R-E)\} \partial t-r \partial A$

$V_{i+1}=V_{i}+Q_{i}-q_{i}-k V_{i}\left(E_{i}-R_{i}\right)-k r_{i}\left(V_{i+1}-V_{i}\right)$

Where $V$ is volume of flooding, $Q$ is inflow, $q$ is outflow, $R$ is rainfall, $E$ is evaporation, $A$ is flooded area, and $r$ is soil moisture recharge. For the initial storage volume, the study assumed one meter depth. A comparison was made between the study water 25 balance results and Sutcliffe and Park (1999) water balance results.

\section{HESSD}

3, 1851-1877, 2006

\section{Estimation of Bahr-El-Jebel flood area by remote sensing}

M. A. H. Shamseddin et al.

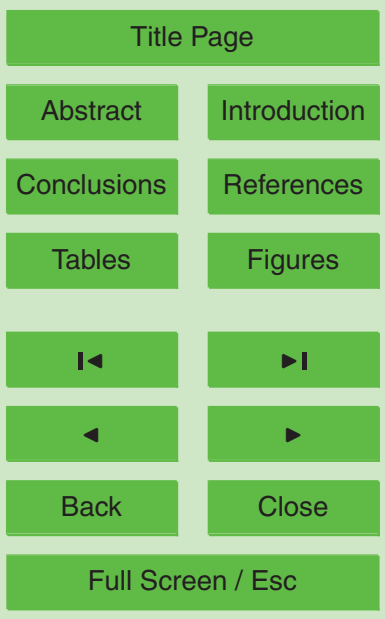

Printer-friendly Version

Interactive Discussion 


\section{Results and discussions}

\subsection{Sudd flooded area}

According to the Lake Victoria water level, the previous studies have differentiated between two distinctive periods, before and after 1964, when the Lake Victoria has 5 risen (Tate et al., 2004; Sutcliffe, 1999; Howell et al., 1996). Due to that raised the Sudd area has trebled (Sutcliffe, 1999). However, after 1970 the estimated areas of flooding decrease fairly steadily (Shahin, 2002).

Table 3 shows the resulted monthly variations of Sudd area (Appendix D). The ratios between the study annual Sudd areas mean, the Sutcliffe's and Park (water balance model prediction) and Mohamed's (SEBAL) were 0.96 and 0.53 , respectively. It's obvious that there is agreement between our results and Sutcliffe's results. From Table 3, March, May, September and November monthly average area looks questionable, as its run out of the averages of the pre and post months. However, a quick glance to Table 4 shows that the trends of these months are coincide with the trends of the Lake Sudd (Tate et al., 2004). It is worth mentioning here that the outflows from the Lake Victoria after the period of 1997-1998 show a decreased trend (Tate et al., 2004). The simple matrix error resulted in $71 \%$ classification accuracy. Figures $3 a$ and b show examples of the resulted study classification images.

$20 \quad$ Figure 4 shows a comparison between Travaglia et al. (1996) Sudd wetlands area (on the basis of AVHRR images, thermal inertia approach) and the results about Sudd flooded area for some selected months. As Travaglia area is wetland and the study area is flooded area, it is accepted that Travaglia results are higher than the study; however, the pattern is same, except in March.

\section{HESSD}

3, 1851-1877, 2006

\section{Estimation of Bahr-El-Jebel flood area by remote sensing}

M. A. H. Shamseddin et al.

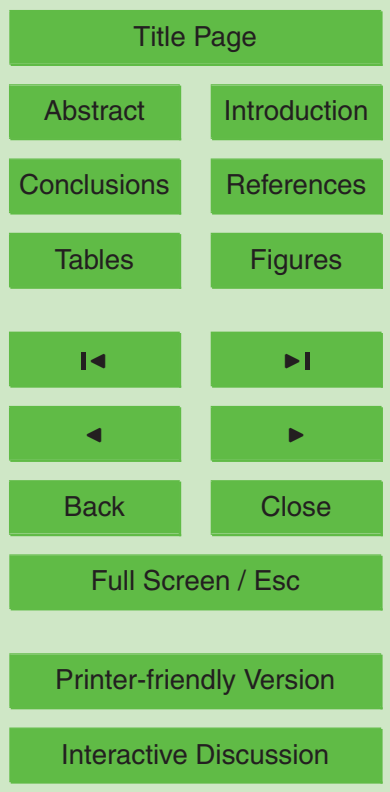




\subsection{Sudd water balance}

The study used two evaporation estimation methods to calculate the mean monthly Sudd $\partial \mathrm{V} / \partial \mathrm{t}$. The first is Sutcliffe and Park open water evaporation (mean 1941-1970), and the second is SEBAL model evaporation estimation. The inflows and outflows

5 inputs were extracted from Sutcliffe and Park (1999), (mean 1961-1983); the rainfall input is the normal mean of the period 1970-2000. In both scenarios the area (A) input was the study Sudd flooded area results. Figure 5 shows the results of the two scenarios. It's clear that from July to September there is agreement between the open water evaporation and SEBAL results, with a relative complete coincidence in August. However, in December, January, February, April, and May Sutcliffe results were more close to the study open water evaporation method scenario. March and November months show the biggest differences between the three results (beginning and end of the rainfall period, respectively). In Fig. 5, the key term "Sutcliffe" refers to the storage changes that calculated by Sutcliffe and Park, on basis of open water evaporation 15 (source Mohamed, 2005).

According to Fig. 6, it's clear that there is abroad agreement between the study (open water evaporation scenario) and Sutcliffe and Park mean monthly storage volume, with a relative high difference in October, November and December. However, SEBAL scenario storage volume shows differences in April, June, October and December. On basis of open water evaporation and SEBAL model evaporation estimation, the mean annual storage volume were 23.0 and $21.7(\mathrm{Gm} 3)$, respectively. The both results were over than Sutcliffe and Park results on basis of open water evaporation $(21.1 \mathrm{Gm} 3)$.

Figures 7 and 8 show comparisons between the mean monthly storage volumes of the Study and Sutcliffe and Park, for the years 2002 and 2004, respectively. The year 2002 shows a higher storage volume for all months, relatively to Sutcliffe and Park storage volume, however, the opposite holds true for the year 2004, except in the last three months.

HESSD

3, 1851-1877, 2006

\section{Estimation of Bahr-El-Jebel flood area by remote sensing}

M. A. H. Shamseddin et al.

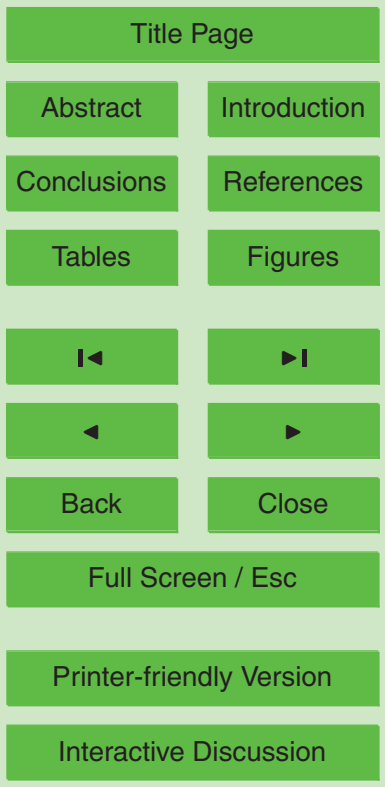




\section{Conclusions and recommendations}

Remote sensing techniques were used to estimate the swamp (Sudd) area. The techniques is considered as the most effective method for swamp area estimation or/and delineation; however, cloud contamination is the main obstacle.

The study found that the annual mean Sudd flooded area is $20400 \mathrm{~km}^{2}$, which is $96 \%$ of Sutcliffe and Park estimation (1999), and 53\% of Mohamed (2005) estimation. However, the swelling and shrinkage of Sudd area is following the trend of Lake Victoria outflow patterns. The annual storage change using open water evaporation estimation shows a coincidence in some months, however, using SEBAL model evaporation estimation shows also a coincidence in some months (especially at the peak of the rainfall period).

Using the open water evaporation estimation with the Sudd flooded area (that resulted from the study) in the Sudd water balance model for calculating the annual storage volume produced 23.0 (Gm3), while the SEBAL model produced $21.7(\mathrm{Gm} 3)$.

15 Both results are higher than the Sutcliffe and Park annual storage volume mean (21.1 Gm3).

The link between the Sudd hydrology and vegetation study is recommended using remote sensing with fine resolution. Instead of assuming a linear relation between the Sudd area and storage volume a detailed study is required.

20 Acknowledgements. The research upon which this paper is based was supported in part by the Grants-in-Aid (No.16405031) for Scientific Research from the Japan Society for the Promotion of Science (JSPS). The research was also supported in part by JSPS AA Science Platform Program. The data used in the study were acquired as part of the NASA's Earth-Sun System Division and archived and distributed by the Goddard Earth Sciences (GES) Data and Informa-

\section{HESSD}

3, 1851-1877, 2006

\section{Estimation of Bahr-El-Jebel flood area by remote sensing}

M. A. H. Shamseddin et al.

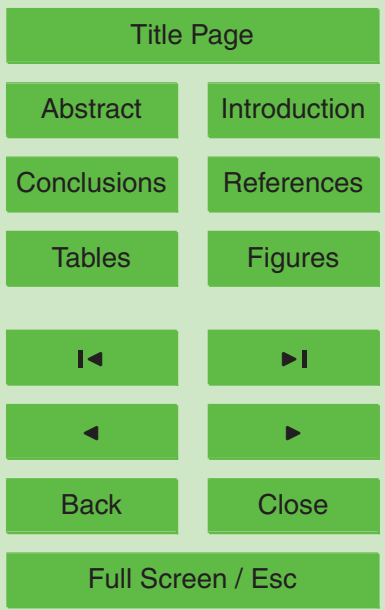

Printer-friendly Version

Interactive Discussion 


\section{References}

Abdelhadi, A. W., Bashir, M. A., Farah, S. M., and Hata, T.: Implications of late sown irrigated grain sorghum on productivity and water management, Sudan J. Agric. Res., 6, 1-10, 2006.

Eldaw, A. K.: Sudan water Resources: Challenge and future perspectives, Water harvesting and Future of development in Sudan, conference, Friendship Hall, Khartoum, Sudan, 2003.

ENVI user's Guide : ENVI version 4.0, September Edition, Research System Inc. (RSI), 2003.

Howell, P. P. and Allan, J. A.: The Nile, sharing a scarce resource, An historical and technical review of water management and of economical and legal issues: Howell \& M. Lock: The control of the swamps of the southern Sudan: Drainage Schemes, local effects and environmental constraints on remedial development, 243-279, Cambridge University Press, 1996.

Mohamed, Y. A.: The Nile Hydroclimatology: Impact of the Sudd Wetland. PhD Dissertation, Delft University of Technology, Netherland, 2005.

Mohamed, Y. A., Saveniji, H. H. G., Bastiaanssen, W. G. M., and Van den Hurk, B. J. J. M.: New Lessons on the Sudd hydrology learned from remote sensing and climate modeling, Hydrol. Earth Syst. Sci. Discuss., 2, 1503-1535, 2005.

Mohamed, Y. A., Van den Hurk, B. J. J. M., Saveniji, H. H. G., and Bastiaanssen,, W. G. M.: Impact of the Sudd wetland on the Nile hydroclimatology, Water Resour. Res., 41, W08420, 2005.

20

Shahin, M.: Hydrology and Water Resources of Africa, Water Science and Technology Library, Kluwer Academic Publishers, Dordrecht/ Boston/ London, 2002.

Sutcliffe, J. and Parks, Y. P.: The Hydrology of the Nile, IAHS Special Publication no. 5, IAHS Press, Institute of Hydrology, Wallingford, Oxfordshire OX10 8BB, UK, p. 33, and 57-87, 1999.

Tate, E., Sutcliffe, J., Declan, C., and Farquharson, F.: Water Balance of Lake Victoria: Update to 2000 and Climate change Modeling to 2100, Hydrol. Sci. J., 49(4), 563-574, 2004.

Travaglia, C., Kapetsky, J. M., and Righini, G.: A Methodology for Monitoring Wetlands for Fisheries Using NOAA AVHRR LAC Thermal Data, 1996.

Waterbury, J.: The Nile Basin, National Determinants of Collective Action, Yale University Press, New Haven and London, 139-149, 2002.

Yamagata, Y.: Advanced remote sensing Techniques for monitoring Complex Ecosystems: Spectral Indices, Unmixing, and Classification of wetlands, Research Report from the Na-

\section{HESSD}

3, 1851-1877, 2006

\section{Estimation of Bahr-El-Jebel flood area by remote sensing}

M. A. H. Shamseddin et al.

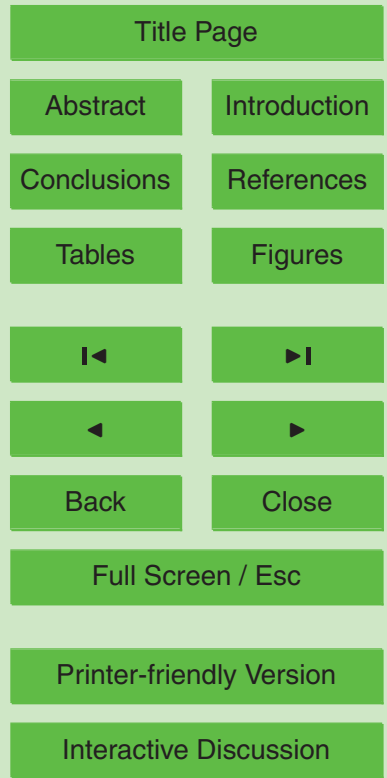


tional Institute for Environmental Studies, Japan, 141, 1999.

HESSD

3, 1851-1877, 2006

Estimation of Bahr-El-Jebel flood area by remote sensing

M. A. H. Shamseddin et al.

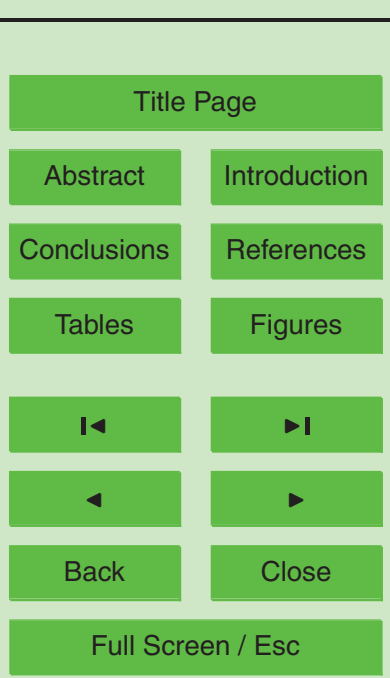

Printer-friendly Version 


\section{HESSD}

$3,1851-1877,2006$

Estimation of Bahr-El-Jebel flood area by remote sensing

M. A. H. Shamseddin et al.

Table 1. The Sudd normal means of some selected climatic elements.

\begin{tabular}{cccc}
\hline Temperature $\left({ }^{\circ} \mathrm{C}\right)$ & Relative humidity $(\%)$ & Sunshine $(\%)$ & Piche evaporation $(\mathrm{mm})$ \\
\hline 28.0 & 55 & 62 & 8.03
\end{tabular}

Source: Sudan Meteorological Corporation.

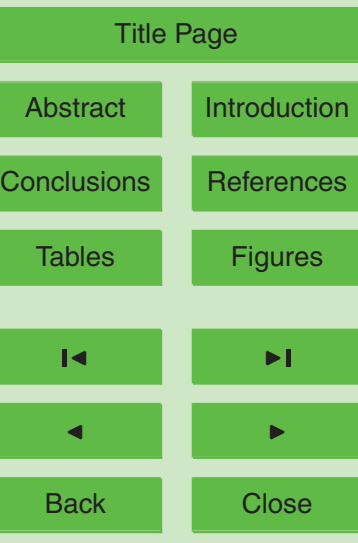

Full Screen / Esc

Printer-friendly Version

Interactive Discussion 


\section{HESSD}

3, 1851-1877, 2006

Estimation of Bahr-El-Jebel flood area by remote sensing

Table 2. Evaporation amount estimation in Sudd area.

M. A. H. Shamseddin et al.

\begin{tabular}{lc}
\hline sources & Evaporation mm/yr \\
\hline Butcher (1938) & 1533 \\
Mojahid (1948) & 2400 \\
Suctcliff (1999) & 2150 \\
Mohamed (2005) & 1636 \\
\hline
\end{tabular}

Source: Mohamed (2005)

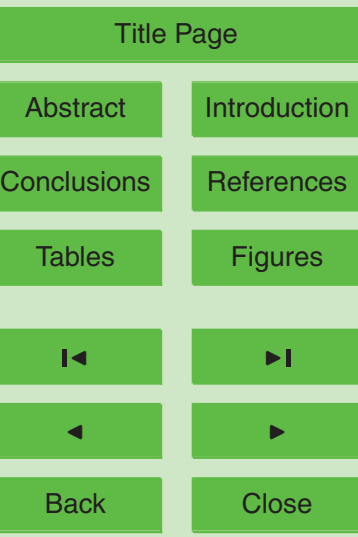

Full Screen / Esc

Printer-friendly Version

Interactive Discussion 


\section{HESSD}

3, 1851-1877, 2006

Estimation of Bahr-El-Jebel flood area by remote sensing

M. A. H. Shamseddin et al.

Table 3. Monthly mean Sudd area $\left(1000 \mathrm{~km}^{2}\right)$ for the period $2001-2005$.

\begin{tabular}{cccccccccccccc}
\hline Month & Jan & Feb & Marrch & April & May & June & July & Aug & Sep & Oct & Nov & Dec & Average \\
\hline Area & 20.9 & 18.9 & 21.5 & 17.1 & 22.6 & 18.0 & 21.5 & 25.0 & 18.0 & 24.7 & 15.6 & 20.4 & 20.4 \\
\hline
\end{tabular}




\section{HESSD}

3, 1851-1877, 2006

Estimation of Bahr-El-Jebel flood area by remote sensing

M. A. H. Shamseddin et

Table 4. Monthly mean Lake Victoria outflows $\left(10^{6} \mathrm{~m}^{3}\right)$ for the period $1961-1990$.

\begin{tabular}{cccccccccccccc}
\hline Month & Jan & Feb & March & April & May & June & July & Aug & Sep & Oct & Nov & Dec & Average \\
\hline Outflow & 3056 & 2811 & 3146 & 3099 & 3331 & 3276 & 3314 & 3242 & 3073 & 3120 & 2955 & 3073 & 37497 \\
\hline
\end{tabular}

Source: Sutcliffe et al. (1999)

References al.

\section{Title Page}

Abstract

Conclusions

Tables

Figures

14

$<$

Back

Close

Full Screen / Esc

Printer-friendly Version

Interactive Discussion 


\section{HESSD}

3, 1851-1877, 2006

\section{Estimation of Bahr-El-Jebel flood area by remote sensing}

Table A1. The previous evaporation studies for Sudd area.

M. A. H. Shamseddin et al.

\begin{tabular}{cccc}
\hline Sources & Average Sudd area (Gm2) & Evaporation mm/yr & Method \\
\hline Butcher (1938) & 7.2 & 1533 & $\begin{array}{c}\text { Papyrus in water tank, } \\
\text { a real photo, and water balance }\end{array}$ \\
Hurst and Black & 8.3 & - & - \\
Mijahid (1948) & - & 2400 & Lysimeter \\
Sutcliffe and Park (1999) & 21.1 & 2150 & Penman formula and Water balance \\
Yasir (2005) & 38.0 & 1636 & Remote sensing and SEBAL \\
\hline
\end{tabular}

Sources: Mohamed (2005)

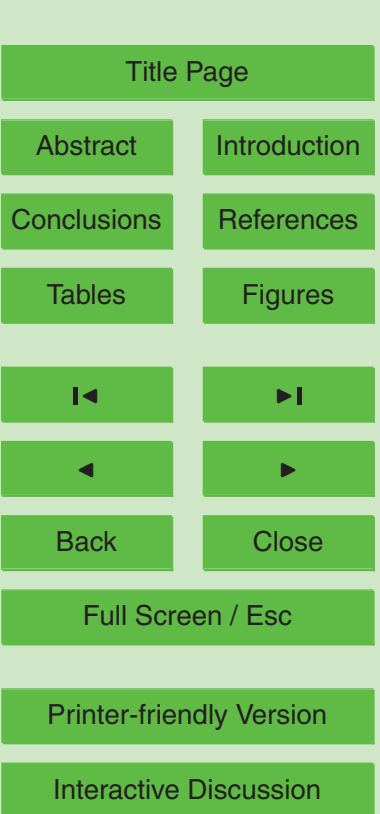




\section{HESSD}

3, 1851-1877, 2006

Estimation of Bahr-El-Jebel flood area by remote sensing

Table B1. List of MODIS images acquisition dates (Julian day).

\begin{tabular}{ccccc}
\hline 2001 & 2002 & 2003 & 2004 & 2005 \\
\hline 25 & 26 & 11 & 9 & 4 \\
36 & 46 & 42 & 36 & 41 \\
46 & 67 & 90 & 55 & 61 \\
84 & 84 & 127 & 80 & 130 \\
146 & 99 & 255 & 103 & \\
313 & 129 & 292 & 110 & \\
331 & 163 & 330 & 126 & \\
345 & 241 & 342 & 297 & \\
& 272 & 362 & 318 & \\
& 346 & & 327 & \\
& & & 361 & \\
& & & &
\end{tabular}

M. A. H. Shamseddin et al.

\section{Title Page}

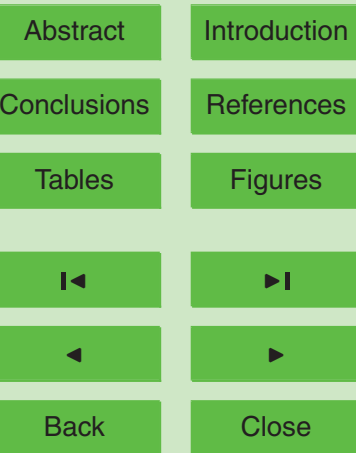

Full Screen / Esc

Printer-friendly Version

Interactive Discussion 


\section{HESSD}

3, 1851-1877, 2006

Estimation of Bahr-El-Jebel flood area by remote sensing

Table C1. List of MODIS bands used.

\begin{tabular}{ccc}
\hline Band & Pixel Resolution $(\mathrm{m})$ & Reflected Bandwidth range $(\mathrm{nm})$ \\
\hline 1 & 250 & $620-670$ \\
2 & 250 & $841-876$ \\
3 & 500 & $459-479$ \\
4 & 500 & $545-565$ \\
5 & 500 & $1230-1250$ \\
6 & 500 & $1628-1652$ \\
7 & 500 & $2105-2155$ \\
\hline
\end{tabular}

M. A. H. Shamseddin et al.

\section{Title Page}

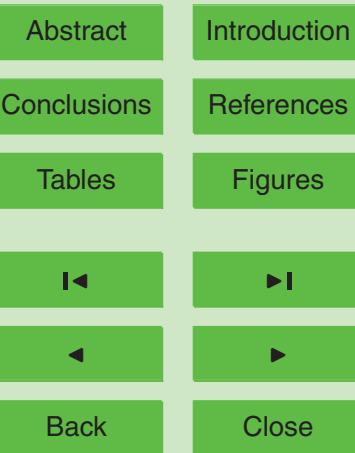

Full Screen / Esc

Printer-friendly Version

Interactive Discussion 


\section{HESSD}

3, 1851-1877, 2006

Table D1. Variation of monthly Sudd area.

\begin{tabular}{cccccc}
\hline Month & 2001 & 2002 & 2003 & 2004 & 2005 \\
\hline Jan & 22.1 & 19 & 21 & 25.3 & 16.9 \\
Feb & 21 & 20 & 20 & 20.8 & 12.8 \\
March & 28 & 21 & - & 19.9 & 16.9 \\
April & - & 21 & - & 13.1 & - \\
May & 23 & 22 & 25 & 24.8 & 18.1 \\
June & - & 18 & - & - & - \\
July & - & - & - & - & - \\
Aug & - & 25 & - & - & - \\
Sep & - & - & 18 & - & - \\
Oct & - & 27 & - & 22.4 & - \\
Nov & 15.5 & - & 14.5 & 16.7 & - \\
Dec & 22 & 14 & 22 & 23.6 & - \\
\hline
\end{tabular}

Estimation of Bahr-El-Jebel flood area by remote sensing

M. A. H. Shamseddin et al.

\section{Title Page}

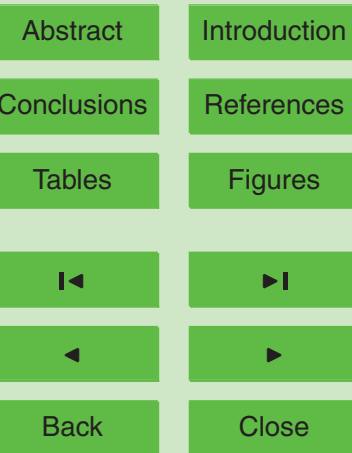

Full Screen / Esc

Printer-friendly Version

Interactive Discussion 


\section{HESSD}

3, 1851-1877, 2006

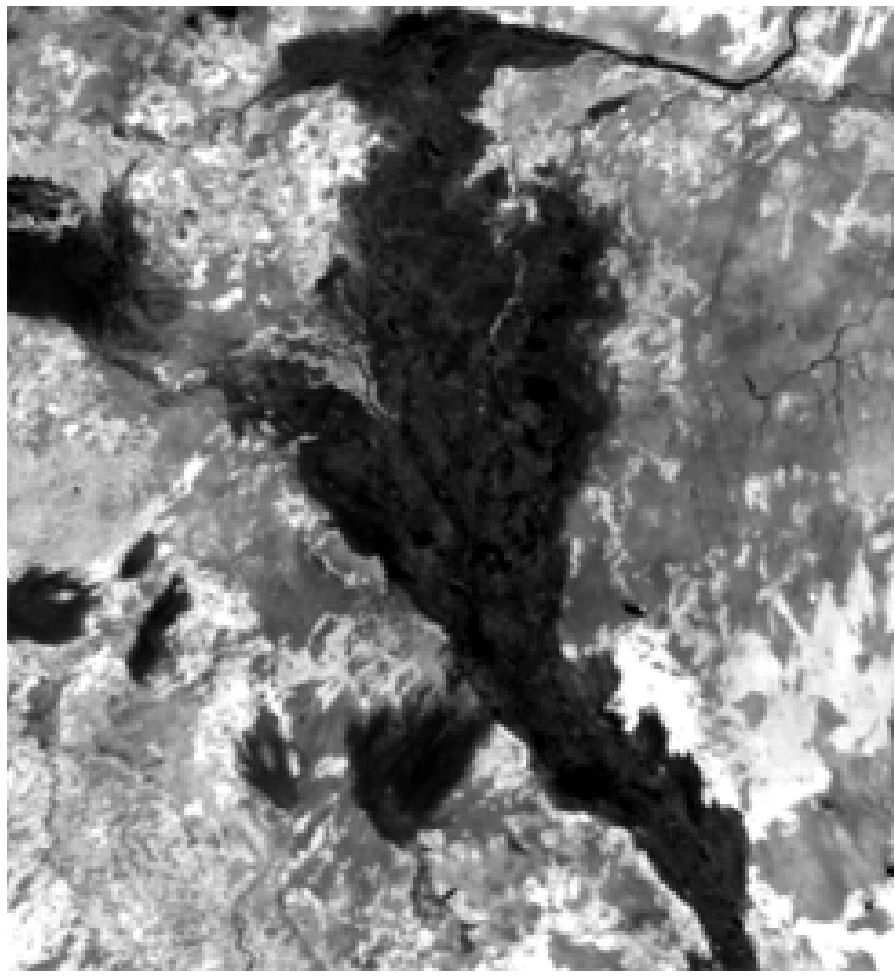

Estimation of Bahr-El-Jebel flood area by remote sensing

M. A. H. Shamseddin et al.

Title Page

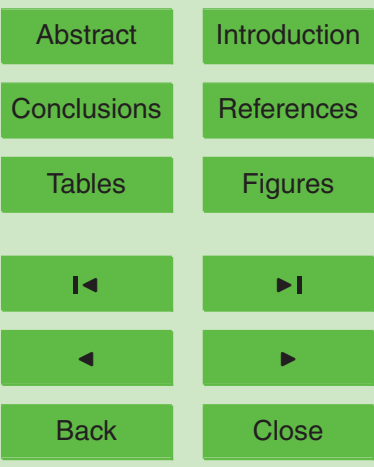

Full Screen / Esc

Fig. 1. Sudd area.

Printer-friendly Version

Interactive Discussion 


\section{HESSD}

3, 1851-1877, 2006

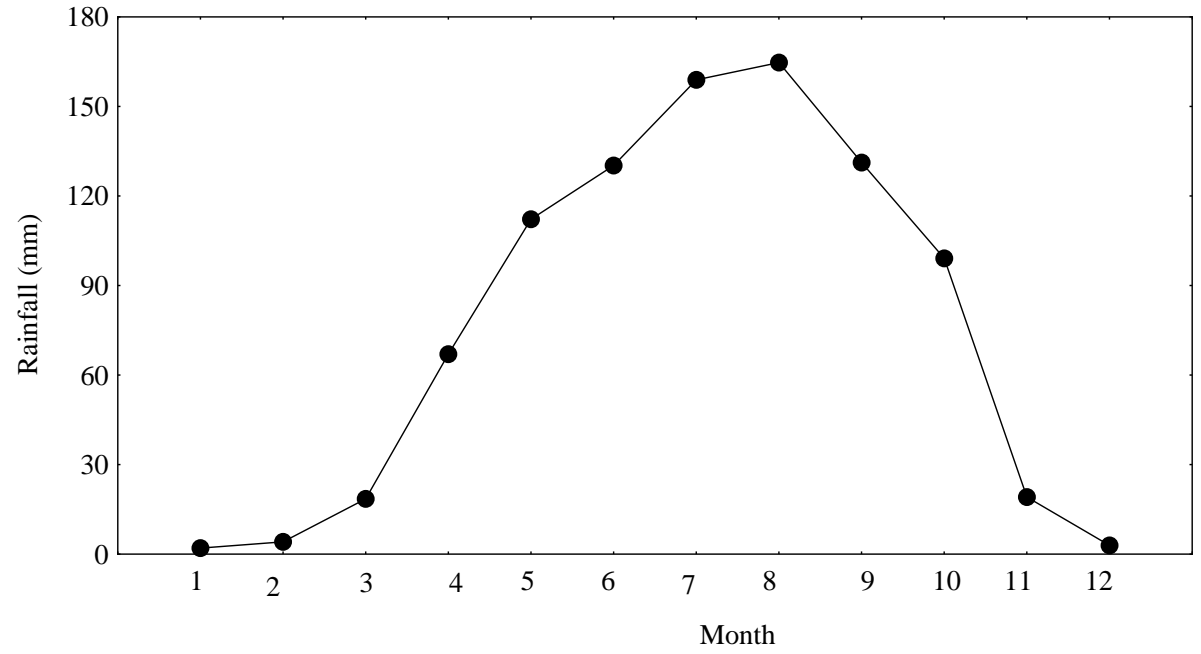

Estimation of Bahr-El-Jebel flood area by remote sensing

M. A. H. Shamseddin et al.

\section{Title Page}

Abstract

Introduction

Conclusions

References

Tables

Figures

14

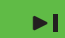

Back

Close

Full Screen / Esc

Printer-friendly Version

Interactive Discussion 


\section{HESSD}

$3,1851-1877,2006$

a

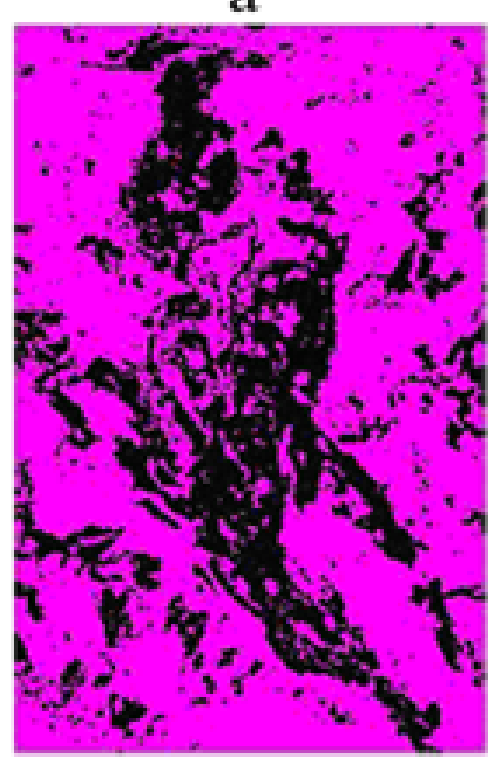

Swamp

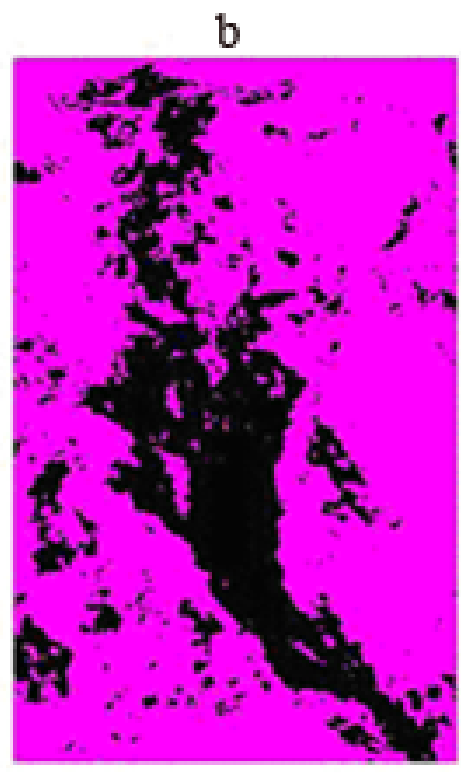

Swamp

Fig. 3. Two consecutive classification images for Sudd (9 January and 24 February 2004).

Estimation of Bahr-El-Jebel flood area by remote sensing

M. A. H. Shamseddin et al.

Title Page

Abstract

Introduction

Conclusions

References

Tables

Figures

14

4

Back

Full Screen / Esc

Printer-friendly Version

Interactive Discussion 


\section{HESSD}

3, 1851-1877, 2006

\section{Estimation of Bahr-El-Jebel flood area by remote sensing}

M. A. H. Shamseddin et al.

\section{Title Page}

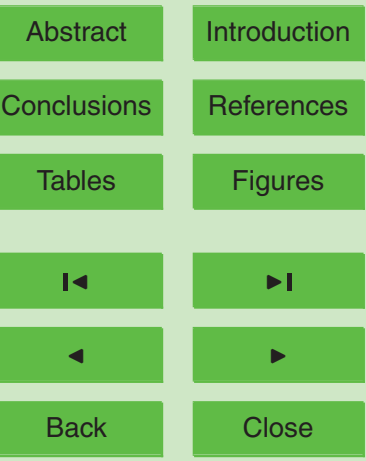

Full Screen / Esc

Printer-friendly Version

Interactive Discussion 


\section{HESSD}

3, 1851-1877, 2006

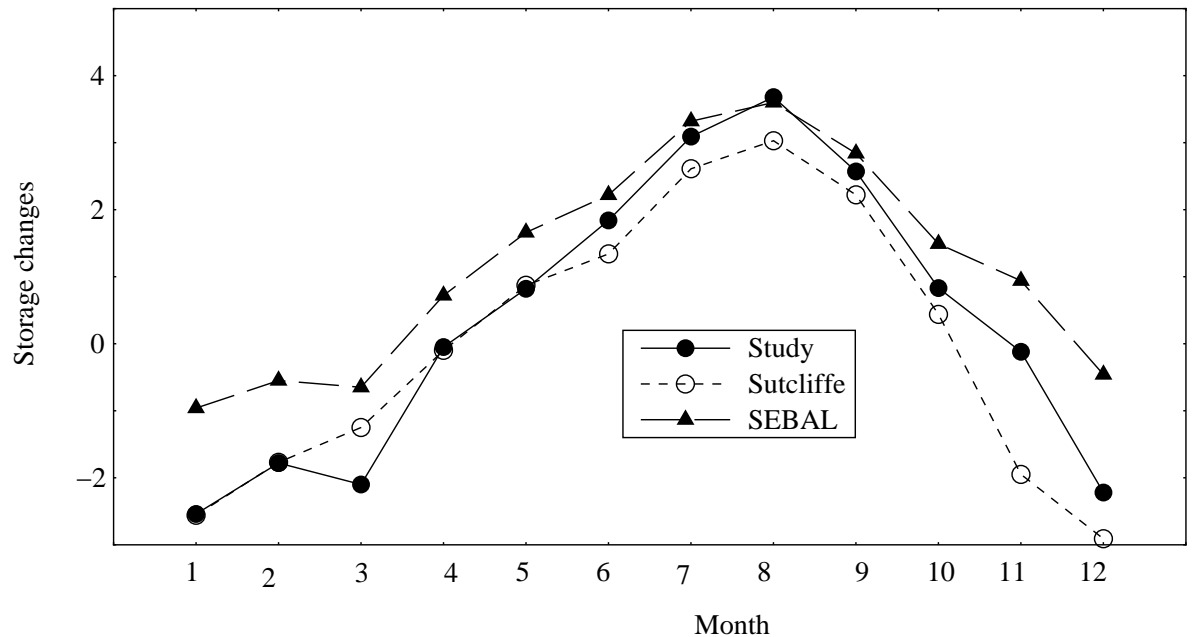
Bahr-El-Jebel flood area by remote sensing

M. A. H. Shamseddin et al.

\section{Title Page}

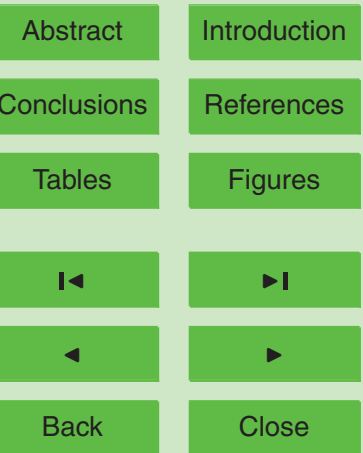

Full Screen / Esc

Printer-friendly Version

Interactive Discussion 


\section{HESSD}

3, 1851-1877, 2006

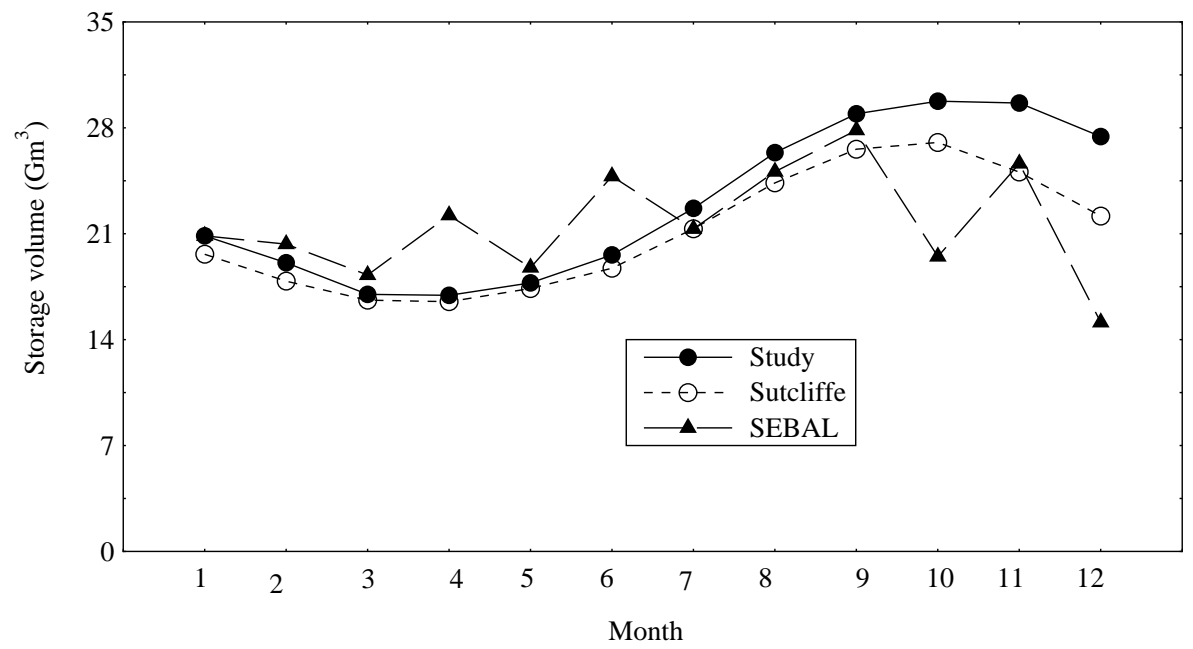

\section{Estimation of Bahr-El-Jebel flood area by remote sensing}

M. A. H. Shamseddin et

Fig. 6. A comparison between the study, Sutcliffe and SEBAL model storage volume (V) for Sudd area.

al.

\section{Title Page}

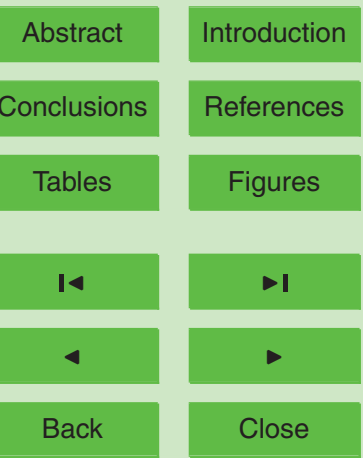

Full Screen / Esc

Printer-friendly Version

Interactive Discussion 


\section{HESSD}

3, 1851-1877, 2006

Estimation of Bahr-El-Jebel flood area by remote sensing

M. A. H. Shamseddin et al.

\section{Title Page}

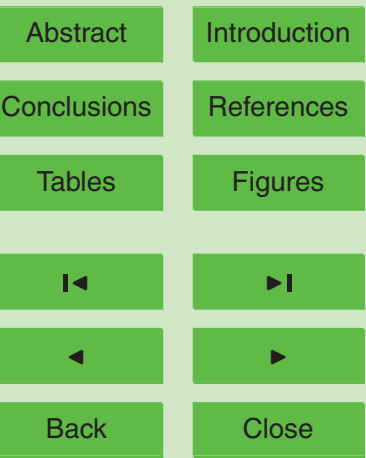

Full Screen / Esc

Printer-friendly Version

Interactive Discussion 


\section{HESSD}

3, 1851-1877, 2006

Estimation of Bahr-El-Jebel flood area by remote sensing

M. A. H. Shamseddin et al.

\section{Title Page}

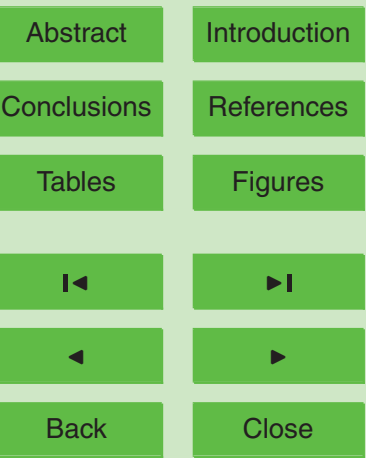

Full Screen / Esc

Printer-friendly Version

Interactive Discussion 